\title{
Latvijā izdotās grāmatas par medicīnas vēsturi (2016-2017)
}

Arnis Vīksna, Aigars Pētersons

Profesors Aleksandrs Bieziṇš un Latvijas bērnu ķirurğija

Rīga: Medicīnas apgāds, 2017. 144 lpp.

ISBN 978-9984-813-95-0

Sērijā "Ievērojamu ārstu dzīve” iznākusi grāmata, kas tika atvērta Aleksandra Bieziņa (1897-1975) 120. dzimšanas dienas atceres sarīkojumā Paula Stradiṇa Medicīnas vēstures muzejā. Tās autori ir divi profesori - medicīnas vēsturnieks Arnis Vīksna un RSU rektors Aigars Pētersons. Grāmata adresēta visiem interesentiem, jo līdzās bērnu ķirurğijai tajā atspoguḷota arī ortopēdijas, traumatologiijas, sporta medicīnas un ārstnieciskās vingrošanas vēsture Latvijā. Grāmata veidota, balstoties uz arhīvu dokumentiem, publikācijām periodikā, laikabiedru atmiņām un agrāk par profesoru rakstīto.

Arnis Vīksna

Hercoga kurpes sudraba sprādze:

šis un tas no medicīnas pagātnes Latvijā

Rīga: Medicīnas apgāds, 2017. 254 lpp.

ISBN 978-9984-813-94-3

Interesantu un sižetiski asu 26 stāstu krājums, kurā autors nav vairījies ne no dramatiskām, ne trağiskām epizodēm Latvijas medicīnas vēsturē pēdējo 300 gadu laikā. Šie stāsti ir vērtīgs izziṇas avots visiem medicīnas vēstures interesentiem. Grāmatas beigās atrodams pielikums ar Latvijas medicīnas vēstures pamatliteratūru no 1762. gada līdz 2016. gadam (ieskaitot). Grāmatu kā dāvanu, beidzot medicīnas studijas, 2017. gadā saṇēma jaunie Latvijas ārsti. 
Maija Pozemkovska, Arnis Vīksna

\section{Latvijas medicīnas vēsturnieki}

Rīga: Medicīnas apgāds, 2017. 112 lpp.

ISBN 978-9984-813-91-2

Grāmatā ietvertā informācija, datu un faktu apkopojums sniedz priekšstatu par pētnieku veikumu Latvijas medicīnas vēsturē. Pētnieki kārtoti hronologískā secībā ar īsbiogrāfiju, kam seko disertācija vai tās autoreferāts, promocijas vai habilitācijas darba kopsavilkums (ja pētījums ir par medicīnas vai farmācijas vēsturi), pēc tam citi darbi - grāmatas vai monogrāfiski apcerējumi, beigās - pētniekam veltīta literatūra (grāmatas, biobibliogrāfija). Šis katalogs ir noderīgs studentiem, muzeju darbiniekiem un bibliogrāfiem, meklējot un apzinot pētījumus Latvijas medicīnas vēsturē.

Rita Grāvere

Tā mēs atgriežamies... : ārsts, anatoms, antropologs

Jēkabs Prīmanis (1892-1971)

Rīga: Skaldu raksti, 2017. 208 lpp.

ISBN 978-9934-8676-0-6

Dr. hist. R. Grāveres ilggadējie pētījumi antropoloǵijā apkopoti Latvijas fiziskās antropologijas patriarham Jēkabam Prīmanim (1892-1971) veltītajā piemiņas grāmatā. Monogrāfija ir bagātīgi ilustrēta ar retām vai līdz šim nepublicētām fotogrāfijām, jo pēc Otrā pasaules kara profesors J. Prīmanis devās emigrācijāa dzīvoja un strādāja Pitsburgā, ASV. Grāmatas izdošanu atbalstījusi Latviešu ārstu un zobārstu apvienība (LĀZA), kuras biedrs ilgus gadus bija J. Prīmanis.

\section{Lāsma Gaitniece}

\section{Dziednīca pie jūras: versija par Liepājas medicīnas vēsturi}

Rīga: Vesta-LK, 2017. 144 lpp.

ISBN 978-9934-51-142-4

Grāmata ir vēstījums par Liepājas medicīnas vēsturi, sākot ar 1830. gadu, kad radās ideja pilsētā būvēt slimnīcu. Grāmatai ir divas daļas. Pirmajā "Liepājas pilsētas slimnīca" - dots ieskats pilsētas medicīnas vēsturē. Otrajā "Slimnīca pēc Otrā pasaules kara un tās ārsti" - apkopotas intervijas vai raksti ar desmit šîs slimnīcas mediķiem. 
Veronika Grišāne

Mēs savai tautai: Latgales ārsti Rēzeknē. 1. daḷa

Rēzekne, 2017. 294 lpp.

ISBN 978-9984-29-285-4

Priekšvārdā autore, Rēzeknes goda pilsone, ārste V. Grišāne, norāda, ka Šì grāmata veidota ar lepnumu par sava novada medicīnas darbinieku uzticīgo kalpošanu līdzcilvēkiem no 1840. līdz 2015. gadam. Tajā atspoguḷoti 100Latgalē dzimušo ārstu dzīvesstāsti un viņu profesionālā darbība Rēzeknē un tās apkaimē, kā arī viṇu neatsveramā un nozīmīgā loma veselības aprūpē. Grāmatas tapšanā izmantots plašs avotu klāsts - Rēzeknes slimnīcas un poliklīnikas arhīvs, ārstu intervijas, publikācijas presē u. c.

Arnis Vīksna

Ārsti. Latvija. Laiks

Rīga: Medicīnas apgāds, 2016. 176 lpp.

ISBN 978-9984-813-87-5

Grāmata par simt izcilākajiem Latvijas ārstiem, kurā atspoguḷots ārsta pašaizliedzīgais darbs savas tautas labā. Tā veidota kā atsevišķi biogrāfiski stāsti, ko papildina ārsta portrets. Grāmatas adresāts vispirms ir medicīnas students. Lai viņšs smeltos iedvesmu, izvēlētos ideālu, kam sekot, jo cildenu un cēlu paraugu un piemēru Latvijas medicīnas pagātnē netrūkst. Kolēgiem ārstiem, kuru redzesloks ir plašāks, tā varētu noderēt kā papildu informācijas avots.

RSU Stomatologijas institūts

\section{Kārlis Barons un viṇa laikmets Latvijas zobārstniecībā, 1865-1944}

Redkolēgija: Ilga Urtāne, Andrejs Skağers, Arnis Vīksna.

(Sērija: Ievērojamu ārstu dzīve)

Rīga: Medicīnas apgāds, 2016. 528 lpp.

ISBN 978-9984-813-88-2

RSU Stomatologijas institūta izdotā grāmata (sērijā "Ievērojamu ārstu dzīve") veidota kā veltījums Latvijas zobārstniecības pamatlicēja profesora Kārḷa Barona 150 gadu jubilejai, kas tika svinēta 2015. gada oktobrī.

Grāmata veidota no četriem jubilejas sēdē nolasītiem referātiem, kas pārstrādāti un papildināti. Tajā ir vairāki pielikumi: K. Barona līdzstrādnieku 1̄sbiogrāfijas, viņa studentu saraksts, vairāku profesora un līdzstrādnieku rakstu faksimili. Šis apkopojums ir Latvijas akadēmiskās zobārstniecības pirmo divdesmit gadu darbības atspogul̦ojums, jo pārpublicēto rakstu autori savulaik bija ievērojami speciālisti. 
Arnis Vīksna

\section{Medicīnas vēstures pieminekḷi Vecrīgā un kanālmalā}

Rīga: LU Akadēmiskais apgāds, 2016. 142 lpp.

ISBN 978-9934-18-099-6

Arņa Vīksnas aizraujošajā cel̦vedī atrodama informācija par Rīgas vecākajām aptiekām, anatomisko teātri, pelēkajām māsām, Nikolaja nabagmāju un citiem medicīnas vēstures objektiem. Grāmatā publicēti 200 gadu veci attēli no O. Hūna (1764-1832) un J. A. Ēzena (1762-1804) darbu izdevumiem, kā arī J. K. Broces (1742-1823) zīmējumi. Cel̦vedī ievietota karte, kurā atzīmēti apskates objekti.

Olga Fokina, Inga Millere

\section{Priestera Vincenta de Paula žēelsirdīgo māsu apvienības}

darbība Latgalē (1789-1864)

Rīga: Rīgas Stradiņa universitāte, 2016. 98 lpp.

ISBN 978-9934-563-03-4

Šì ir Latvijā pirmā grāmata, kurā sniegts vēsturisks pārskats par priestera Vincenta de Paula žēlsirdīgo māsu apvienību, tās principiem un žēlsirdīgo māsu misiju, aprakstot to kultūrvēsturiskā aspektā un vienlaikus atainojot arī māsu profesijas aizsākumus. Grāmatā tiek aplūkotas Latvijā līdz šim nezināmas medicīnas māsu profesijas vēstures lappuses.

Lai taptu grāmata, tika studēti Lietuvas Valsts vēstures arhīva un Baltkrievijas Nacionālā vēstures arhīva materiāli. Vēsturisko avotu izpētē nozīmīgs materiāls gūts publikācijās, kuras atrodamas Polijas, Lietuvas un Latvijas bibliotēkās.

\section{Ivars Siliņš}

\section{Mans gājiens: profesora Ivara Siliṇa atmiṇas}

Rīga: Skaldu raksti, 2016. 208 lpp.

ISBN 978-9934-14-989-4

Rīgas Medicīnas institūta (tagad - RSU) 1956. gada absolvents, ārsts kardiologs ar 59 gadu darba stāžu medicīnā, zinātnieks, Triju Zvaigžṇu ordeṇa virsnieks profesors Ivars Siliņš strādājis slimnīcā "Gaiļezers" kopš tās atvēršanas 1979. gadā un ilgus gadus bijis Iekšks̄ịo slimību klīnikas vadītājs. "Mans gājiens" ir I. Siliṇa atmiṇu stāsts ar daudziem pieturas punktiem un pārdomu brīžiem. Grāmatā pieminēti vai raksturoti daudzi sabiedrībā pazīstami ārsti un docētāji.

\footnotetext{
Maija Pozemkovska

Dr. med., Rīgas Stradiṇa universitātes Medicīnas vēstures institūts, docente / Institute of the History of Medicine at Rìga Stradiņš University, docent
} 